\title{
Enzymatic synthesis of radiolabeled phosphonoacetaldehyde ${ }^{\text {ir }}$
}

\author{
Guofeng Zhang, ${ }^{\text {a Karen N. Allen, }{ }^{\mathrm{b}} \text { and Debra Dunaway-Mariano,* }}$ \\ ${ }^{a}$ Department of Chemistry, University of New Mexico, Albuquerque, NM 87131-0001, USA \\ ${ }^{\mathrm{b}}$ Department of Physiology and Biophysics, Boston University School of Medicine, Boston, MA 02118-2394, USA
}

Received 11 June 2003

\begin{abstract}
Phosphonoacetaldehyde (Pald) is formed in a variety of biosynthetic pathways leading to natural phosphonates and is an intermediate in the degradation pathway of the natural product 2-aminoethylphosphonate. To facilitate the investigation of the enzymes catalyzing these pathways, a method for the synthesis of radiolabeled Pald was developed. The enzyme pyruvate phosphate dikinase was used to prepare phosphoenolpyruvate (PEP) from pyruvate, adenosine triphosphate (ATP), and orthophosphate. Then PEP was converted to phosphonopyruvate (Ppyr) with PEP mutase and then to Pald with Ppyr decarboxylase. By using $\left[\beta-{ }^{32} \mathrm{P}\right] \mathrm{ATP}$ or $\left[2-{ }^{14} \mathrm{C}\right]$ pyruvate as precursor, $\left[{ }^{32} \mathrm{P}\right] \mathrm{Pald}$ or $\left[1-{ }^{14} \mathrm{C}\right] \mathrm{Pald}$ was obtained, respectively. The utilization of the synthetic, radiolabeled Pald as a probe of enzyme mechanism was demonstrated with the enzyme phosphonoacetaldehyde hydrolase (trivial name phosphonatase). The single turnover time course for the formation and consumption of radiolabeled covalent enzyme species evidenced a kinetically competent covalent intermediate.
\end{abstract}

(C) 2003 Elsevier Inc. All rights reserved.

Keywords: Phosphonate; Phosphonoacetaldehyde; $\left[{ }^{32} \mathrm{P}\right] \mathrm{Pald}$; $\left[{ }^{14} \mathrm{C}\right] \mathrm{Pald}$; Radiolabel; Enzymatic synthesis

Radiolabeled probes have applications in biological studies, such as tracing the distribution and usage of a metabolite in an organism, monitoring the absorption and excretion kinetics of drugs in the body, and identifying the chemical steps of metabolic pathways. At the enzyme level, radiolabeled substrates are used in activity assays and in determination of the mechanism of catalysis. Mechanistic studies that focus on the characterization of reaction intermediates often rely on the use of radiolabeled reactants in combination with rapid quench technology [1].

Phosphonoacetaldehyde (Pald) ${ }^{1}$ is an intermediate in a variety of biosynthetic pathways leading to natural phosphonates and an intermediate in the degradation pathway of the most ubiquitous phosphonate, 2-aminoethylphosphonate (Fig. 1) [2,3]. Phosphonates are syn-

\footnotetext{
This work was supported by NIH Grant GM61099.

* Corresponding author. Fax: 1-505-277-2609.

E-mail address: dd39@unm.edu (D. Dunaway-Mariano).

${ }^{1}$ Abbreviations used: Pald, phosphonoacetaldehyde; SA, specific activity; PPDK, pyruvate phosphate dikinase; Ppyr, phosphonopyruvate; $\mathrm{PEP}$, phosphoenolpyruvate; $\mathrm{P}_{\mathrm{i}}$, orthophosphate; $\mathrm{PP}_{\mathrm{i}}$, pyrophosphate; cpm, counts per minute.
}

thesized in microbes and lower animals to carry out specialized functions which include microbe eradication, cell-cell signaling, host infection and/or persistence, or phosphorus storage (reviewed in [4] and references therein). To facilitate the study of the biosynthetic pathways leading to phosphonate natural products and the enzymes catalyzing these pathways, radiolabeled Pald was prepared as a probe.

Here, we report an enzymatic synthetic pathway leading to $\left[{ }^{32} \mathrm{P}\right] \mathrm{Pald}$ and $\left[1-{ }^{14} \mathrm{C}\right] \mathrm{Pald}$. To demonstrate their application in enzyme mechanism studies these two probes were used to identify a covalent enzyme intermediate formed during Pald hydrolysis catalyzed by the enzyme phosphonoacetaldehyde hydrolase (hereafter called phosphonatase; EC 3.11.1.1).

\section{Materials and methods}

\section{Materials}

$\left[2-{ }^{14} \mathrm{C}\right]$ pyruvic acid sodium salt (specific activity $(\mathrm{SA})=23 \mathrm{mCi} / \mathrm{mmol})$ and $\left[\beta{ }^{32} \mathrm{P}\right] \mathrm{ATP}(\mathrm{SA}=7000 \mathrm{mCi} /$ $\mathrm{mmol}$ ) were purchased from Perkin-Elmer Life sciences. 


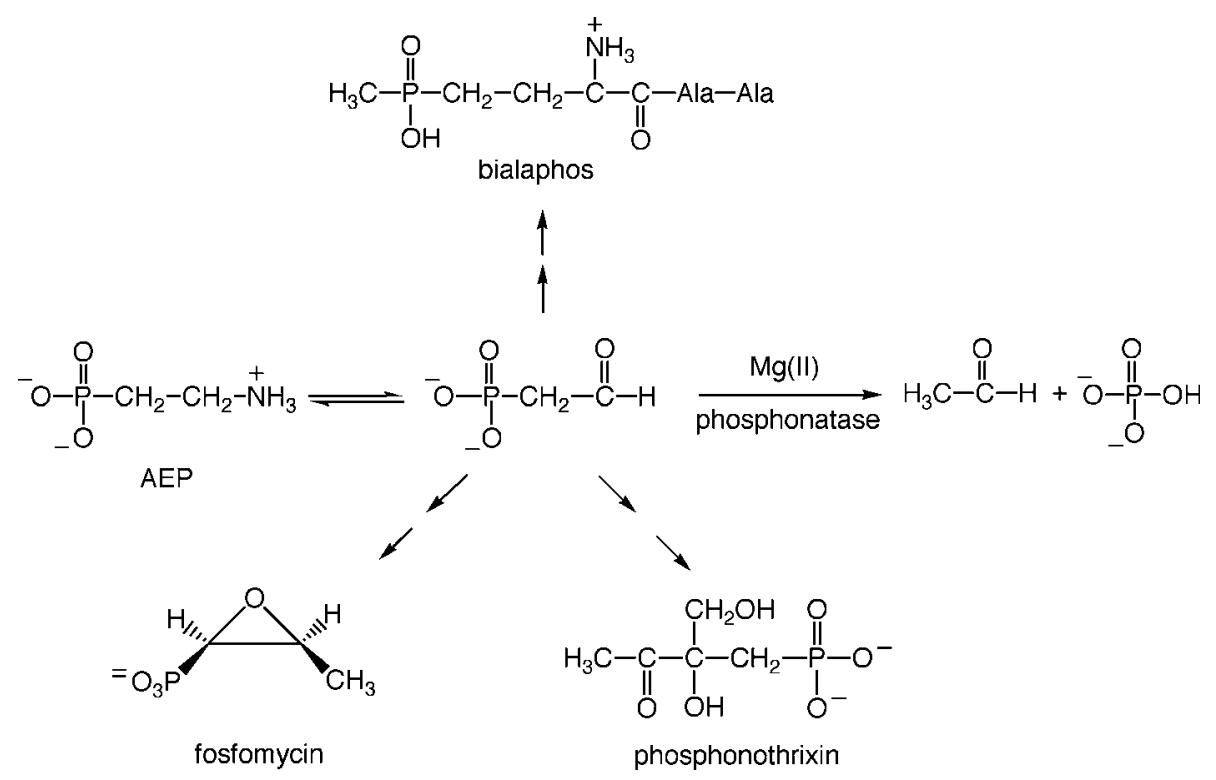

Fig. 1. Phosphonate pathways involving Pald, illustrated by its incorporation into the biologically active compounds and its degradation.

Recombinant Clostridium symbiosum pyruvate phosphate dikinase (PPDK) was prepared according to the published procedure [5]. Bacteroides fragilis phosphonopyruvate (Ppyr) decarboxylase was prepared as described [6]. Recombinant Mytilus edulis phosphoenolpyruvate (PEP) mutase, prepared according to published procedure, was kindly provided by Mr. Zhibing $\mathrm{Lu}$ in this laboratory [7]. Yeast inorganic pyrophosphatase was purchased from Sigma. Recombinant wild-type and mutant phosphonatases were prepared according to [8]. Thiamine pyrophosphate, unlabeled pyruvate and ATP, and all buffer components were the highest grade purchased from Sigma-Aldrich and were used without further purification.

\section{Synthesis of $\left[1-{ }^{14} \mathrm{C}\right]$ Pald}

A $1-\mathrm{ml}$ reaction solution contained $50 \mathrm{mM} \mathrm{K}^{+}$Hepes (pH 7.0), $20 \mathrm{mM}$ ATP, $5 \mathrm{mM}\left[2-{ }^{14} \mathrm{C}\right]$ pyruvic acid $(\mathrm{SA}=23 \mathrm{mCi} / \mathrm{mmol}), 20 \mathrm{mM} \mathrm{Na} \mathrm{PO}_{4}, 5 \mathrm{mM} \mathrm{MgCl}_{2}$, $40 \mathrm{mM} \mathrm{NH}_{4} \mathrm{Cl}, 4.5 \mu \mathrm{M}$ PPDK, and 5 units of inorganic pyrophosphatase (excess ATP and pyrophosphate hydrolysis, catalyzed by inorganic pyrophosphatase, were used to drive the reaction to completion). The reaction was allowed to stand at $25^{\circ} \mathrm{C}$ for $1 \mathrm{~h}$ and then applied to a $1.5 \times 40-\mathrm{cm}$ DEAE Sepharose column equilibrated with $0.1 \mathrm{M}$ triethylamine bicarbonate $(\mathrm{pH} 7.2)$. The column was eluted at $25^{\circ} \mathrm{C}$ with a $1.6-\mathrm{L}$ linear gradient $(0.1$ to $0.4 \mathrm{M})$ of triethylamine bicarbonate $(\mathrm{pH} 7.2)$ at a flow rate of $200 \mathrm{ml} / \mathrm{h}$. The column fractions $(20 \mathrm{ml} /$ fraction) were assayed for radioactivity by dissolving an aliquot in Ready Safe liquid scintillation cocktail (Beckman Coulter) and carrying out liquid scintillation counting with a Beckman LS 6500 multipurpose Scintillation Counter. The PEP-containing fractions (eluted at $\sim 0.28-0.30 \mathrm{M}$ triethylamine bicarbonate) were combined and concentrated in vacuo to $1 \mathrm{ml}$ by rotatory evaporation at $25^{\circ} \mathrm{C}$. The sample was twice diluted with $10 \mathrm{ml}$ of deionized water and concentrated to remove triethylamine bicarbonate. The resulting clear oil ( $\sim 0.5 \mathrm{ml} ; 50 \%$ yield) was diluted to $1 \mathrm{ml}$ with deionized water and stored at $-20^{\circ} \mathrm{C}$. The purity of the $\left[2-{ }^{14} \mathrm{C}\right] \mathrm{PEP}$ sample was confirmed by HPLC analysis: retention time $8.35 \mathrm{~min}$ (same as PEP standard) (Beckman Coulter System Gold instrument equipped with Phenomenex phenosphere SAX 00 G-3151-E0 ion-exchange column; mobile phase $0.4 \mathrm{M} \mathrm{KCl}, 0.1 \mathrm{M} \mathrm{KH}_{2} \mathrm{PO}_{4}, \mathrm{pH} 5.0 ; 0.7 \mathrm{ml} /$ min flow rate).

$\left[1-{ }^{14} \mathrm{C}\right]$ Pald was synthesized immediately before use according to the following procedure. A $0.5-\mathrm{ml}$ reaction solution containing $50 \mathrm{mM} \mathrm{K}{ }^{+}$Hepes (pH 7.5), $200 \mu \mathrm{M}$ $\left[2-{ }^{14} \mathrm{C}\right] \mathrm{PEP}(\mathrm{SA}=23 \mathrm{mCi} / \mathrm{mmol}), 10 \mathrm{mM} \mathrm{MgCl} 2,4 \mathrm{mM}$ thiamine diphosphate, $5 \mu \mathrm{M}$ recombinant $M$. edulis PEP mutase, and $5 \mu \mathrm{M}$ Ppyr decarboxylase was incubated at $25^{\circ} \mathrm{C}$ for $1 \mathrm{~h}$. The enzymes were removed by centrifugation of the solution through a $5-\mathrm{kDa}$ cutoff filter (twice) and the $\left[1-{ }^{14} \mathrm{C}\right] \mathrm{Pald}$ was used without further purification. The $\left[1-{ }^{14} \mathrm{C}\right]$ Pald sample was confirmed by HPLC analysis: retention time $6.23 \mathrm{~min}$ (same as chemical standard) (Beckman Coulter System Gold instrument equipped with Phenomenex phenosphere SAX $00 \mathrm{G}-3151-\mathrm{E} 0$ ion-exchange column; mobile phase $0.4 \mathrm{M}$ $\mathrm{KCl}, 0.1 \mathrm{M} \mathrm{KH}_{2} \mathrm{PO}_{4}, \mathrm{pH} 5.0 ; 0.7 \mathrm{ml} / \mathrm{min}$ flow rate).

The yield $(>95 \%)$ of prepared Pald $(0.2 \mathrm{mM})$ was determined using unlabeled PEP treated under the same conditions employed with the radiolabeled PEP. The concentration of Pald in the product sample was measured with a spectrophotometric assay based on the phosphonatase reaction. Accordingly, a $0.5-\mathrm{ml}$ aliquot from the product solution was added to a 1-ml assay 
solution containing $0.01 \mu \mathrm{M}$ phosphonatase, 5 units of alcohol dehydrogenase, $200 \mu \mathrm{M} \quad \beta-\mathrm{NADH}, \quad 10 \mathrm{mM}$ $\mathrm{MgCl}_{2}$, and $50 \mathrm{mM} \mathrm{K}^{+}$Hepes $\left(\mathrm{pH} 7.5,25^{\circ} \mathrm{C}\right)$ in a $1-\mathrm{cm}-$ path-length cell. The ratio of the $\Delta$ Abs $(340 \mathrm{~nm})=0.6$ ODU and the molar extinction coefficient $=6200$ $\mathrm{M}^{-1} \mathrm{~cm}^{-1}$ were used to calculate the Pald concentration.

\section{Synthesis of $\left[{ }^{32} P\right]$ Pald}

A 1-ml reaction solution contained $50 \mathrm{mM} \mathrm{K}^{+}$Hepes (pH 7.0), $1 \mathrm{mM}\left[\beta-{ }^{32} \mathrm{P}\right] \mathrm{ATP} \quad(\mathrm{SA}=7000 \mathrm{mCi} / \mathrm{mmol})$, $20 \mathrm{mM}$ pyruvic acid, $20 \mathrm{mM} \mathrm{Na} \mathrm{PO}_{4}, 5 \mathrm{mM} \mathrm{MgCl}_{2}$, $40 \mathrm{mM} \mathrm{NH}_{4} \mathrm{Cl}, 4.5 \mu \mathrm{M}$ PPDK, and 5 units of inorganic pyrophosphatase. Excess pyruvic acid and inorganic pyrophosphatase were used to drive the reaction to completion. The $\left[{ }^{32} \mathrm{P}\right] \mathrm{PEP}$ was purified and concentrated using the same procedure described for $\left[2-{ }^{14} \mathrm{C}\right] \mathrm{PEP}$. The resulting clear oil $(\sim 0.2 \mathrm{ml})$ was diluted to $0.5 \mathrm{ml}$ with deionized water and stored at $-20^{\circ} \mathrm{C}$. The purity of the stock was checked by HPLC (the same conditions as described above).

$\left[{ }^{32} \mathrm{P}\right]$ Pald was synthesized just before use employing the following procedure. A $0.5-\mathrm{ml}$ reaction solution containing $50 \mathrm{mM} \mathrm{K}{ }^{+}$Hepes ( $\left.\mathrm{pH} 7.5\right), 200 \mu \mathrm{M}\left[{ }^{32} \mathrm{P}\right] \mathrm{PEP}$ $(\mathrm{SA}=5000 \mathrm{mCi} / \mathrm{mmol}), 10 \mathrm{mM} \mathrm{MgCl} 2,4 \mathrm{mM}$ thiamine diphosphate, $5 \mu \mathrm{M} M$. edulis PEP mutase, and $5 \mu \mathrm{M}$ Ppyr decarboxylase was incubated at $25^{\circ} \mathrm{C}$ for $1 \mathrm{~h}$. The enzymes were removed from the solution and the identity and concentration of the Pald product $(0.2 \mathrm{mM}$; $\sim 100 \%$ yield) determined as previously described for the $\left[1-{ }^{14} \mathrm{C}\right]$ Pald.

\section{Trapping the covalent enzyme intermediates formed in the phosphonatase reaction using rapid quench}

All rapid quench experiments were performed at $10^{\circ} \mathrm{C}$ using a rapid-quench instrument from KinTek Instruments (the three-syringe model) equipped with a thermostatically controlled circulator; the reaction buffer was $50 \mathrm{mM} \mathrm{K}^{+}$Hepes, $\mathrm{pH} 7.5$, containing $10 \mathrm{mM}$ $\mathrm{MgCl}_{2}$ (buffer A). A typical experiment was carried out by mixing $30 \mu \mathrm{l}$ buffer A containing $1000 \mu \mathrm{M}$ phosphonatase (wild type or the inactive mutant K53R [8]) and
$32 \mu \mathrm{l}$ buffer A containing $20 \mu \mathrm{M}$ freshly prepared [1$\left.{ }^{14} \mathrm{C}\right]$ Pald or $\left[{ }^{32} \mathrm{P}\right]$ Pald. The reactions were quenched after a specified period of time with $182 \mu 10.6 \mathrm{M} \mathrm{HCl}$ (if the reaction time was shorter that $75 \mathrm{~ms}$, then additional $0.6 \mathrm{M} \mathrm{HCl}$ was added to adjust the total volume of the quench reagent to $182 \mu \mathrm{l})$. Following the addition of $50 \mu \mathrm{CCl}_{4}$, the mixture was mixed by vortexing vigorously for $20 \mathrm{~s}$. The mixture was centrifuged at $14,000 \mathrm{rpm}$ for $2 \mathrm{~min}$. The liquid was removed and the protein pellet was carefully blotted on a piece of $\mathrm{Ki}$ mwipe paper. The dried pellet was dissolved in $0.2 \mathrm{ml}$ $10 \mathrm{~N} \mathrm{H}_{2} \mathrm{SO}_{4}$ at $100{ }^{\circ} \mathrm{C}$ for $1 \mathrm{~min}$ and then added to $4 \mathrm{ml}$ of Ready Safe liquid scintillation cocktail for counting. The background (measured by denaturing the enzyme prior to mixing the enzyme and substrate or using the inactive mutant $\mathrm{K} 53 \mathrm{R}$ in place of the wild-type phosphonatase) was subtracted from each reading. The net radioactivity was used to calculate the concentration of covalently modified enzyme, by multiplying the initial Pald concentration by the fraction of the total radioactivity present in the isolated enzyme.

\section{Results and discussion}

The goal of this work was to develop a method to synthesize $\left[1-{ }^{14} \mathrm{C}\right] \mathrm{Pald}$ and $\left[{ }^{32} \mathrm{P}\right] \mathrm{Pald}$. The reaction sequence used to this end is outlined in Fig. 2. In the first step of this sequence, the enzyme pyruvate phosphate dikinase catalyzes the interconversion of ATP, $\mathrm{P}_{\mathrm{i}}$, and pyruvate with AMP, $\mathrm{PP}_{\mathrm{i}}$, and $\mathrm{PEP}$. The reaction is driven to completion (in the PEP-forming direction) by inorganic pyrophosphatase-catalyzed hydrolysis of $\mathrm{PP}_{\mathrm{i}}$. For the synthesis of $\left[2-{ }^{14} \mathrm{C}\right] \mathrm{PEP}$, commercial $\left[2-{ }^{14} \mathrm{C}\right] \mathrm{py}-$ ruvate is reacted with excess ATP and $\mathrm{P}_{\mathrm{i}}$. For the synthesis of $\left[{ }^{32} \mathrm{P}\right] \mathrm{PEP}$, commercial $\left[\beta{ }^{32} \mathrm{P}\right] \mathrm{ATP}$ is reacted with excess pyruvate and $\mathrm{P}_{\mathrm{i}}$. The $(>99 \%)$ pure radiolabeled PEP is obtained in 50\% yield by anion-exchange column chromatography of the reaction mixture. The specific activity of the $\left[2-{ }^{14} \mathrm{C}\right] \mathrm{PEP}$ prepared in this manner was $23 \mathrm{mCi} / \mathrm{mmol}$ while that of the $\left[{ }^{32} \mathrm{P}\right] \mathrm{PEP}$ was $5000 \mathrm{mCi} / \mathrm{mmol}$ (calculated from the SA of the $\left[\beta-{ }^{32} \mathrm{P}\right] \mathrm{ATP}$ and the known decay rate).
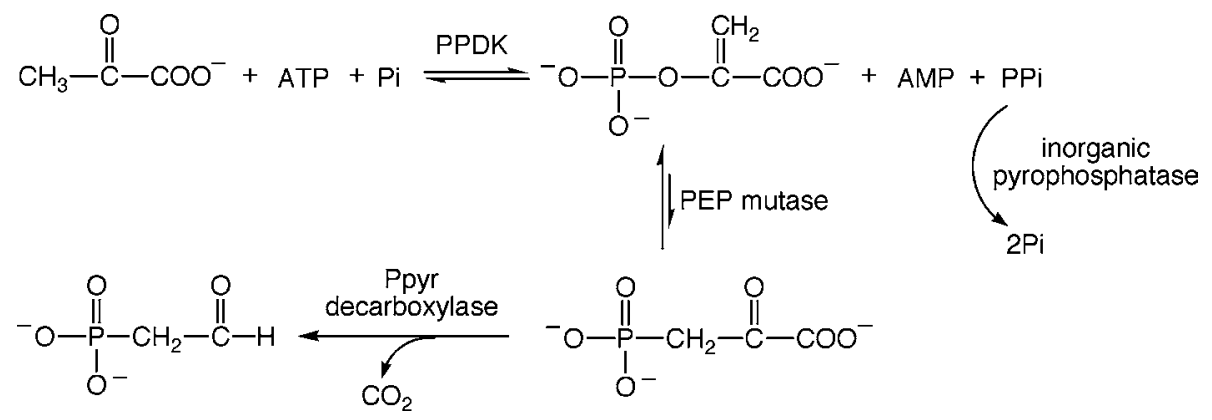

Fig. 2. Enzymatic synthetic pathway of the radiolabeled Pald. PPDK, pyruvate phosphate dikinase; PEP mutase, phosphoenolpyruvate/phosphonopyruvate phosphomutase; Ppyr, phosphonopyruvate. 
Based on our own experience, radiolabeled PEP is chemically stable when stored in deionized water at $-20^{\circ} \mathrm{C}$, while radiolabeled Pald is not. Thus, when desired for use, the radiolabeled Pald is generated from the radiolabeled PEP precursor in $>95 \%$ yield and with the same specific activity as that of the starting PEP. As shown Fig. 2, this is accomplished via the actions of two enzymes: PEP mutase and Ppyr decarboxylase. PEP mutase catalyzes the intramolecular rearrangement of PEP to Ppyr. This reaction is thermodynamically unfavorable $\left(K_{\text {eq }} \sim 1 \times 10^{-3}\right)$ [9]. The ensuing decarboxylation step catalyzed by Ppyr decarboxylase is required to drive the Ppyr-forming reaction forward. Thus, acting together, the mutase and decarboxylase convert PEP to Pald. The enzymes are removed from the sample by size filtration. If needed, the $\operatorname{Mg}(\mathrm{II})$ can be removed with chelex resin. Remaining is the thiamine pyrophosphate, which can be employed in the reaction at a much reduced concentration $(10 \mu \mathrm{M})$. Likewise, the Hepes buffer can be reduced in concentration or a different buffer substituted. Attempts to purify the Pald using anion-exchange column chromatography (such as that used in the purification of the radiolabeled PEP) resulted in degradation of the Pald during the dilution-evaporation cycles.

The utilization of the synthetic, radiolabeled Pald as a probe of enzyme mechanism was demonstrated with the enzyme phosphonatase. As illustrated in Fig. 3, phosphonatase catalysis of Pald hydrolysis to acetaldehyde and orthophosphate proceeds via several covalent enzyme intermediates. Of these covalent intermediate species, only the Lys $53 N$-ethylenamine(III) has been trapped by borohydride reduction during steady state turnover [10].

In this experiment $\left[1-{ }^{14} \mathrm{C}\right] \mathrm{Pald}$ and $\left[{ }^{32} \mathrm{P}\right] \mathrm{Pald}$ were used in a single turnover reaction (i.e., concentration of phosphonatase $\gg$ concentration of radiolabeled Pald), terminated at varying conversion levels by rapid acid-quench, to identify one or more of the covalent adducts represented in Fig. 3. Following the quench, the enzyme was precipitated from the reaction and analyzed for radioactivity. The enzyme fractions isolated from control reactions (viz. reaction between the inactive phosphonatase mutant Lys53Arg and the radiolabeled Pald, or acidquench added to wild-type phosphonatase before reaction with radiolabeled Pald) contained only $\sim 2 \%$ of the total counts measured for the ${ }^{14} \mathrm{C}$-labeled enzyme ( $\sim 60$ to 80 compared to $\sim 2800$ to $3000 \mathrm{cpm})$ and only $\sim 6 \%(\sim 300$ to $400 \mathrm{cpm}$ compared to $\sim 4500$ to $5000 \mathrm{cpm}$ ) of the total counts measured for the $\left[{ }^{32} \mathrm{P}\right]$-labeled enzyme.

Fig. 4 shows the time courses measured for formation and consumption of ${ }^{14} \mathrm{C}$-labeled or ${ }^{32} \mathrm{P}$-labeled enzyme in the single turnover reaction. In both cases, the radiolabeled enzyme reached a maximum level of $\sim 15 \%$ of the limiting substrate at $50-60 \mathrm{~ms}$ and then decreased to near zero within $400 \mathrm{~ms}$. Phosphonatase has a $k_{\text {cat }}$ of $15 \mathrm{~s}^{-1}$; hence, the single turnover reaction should be completed

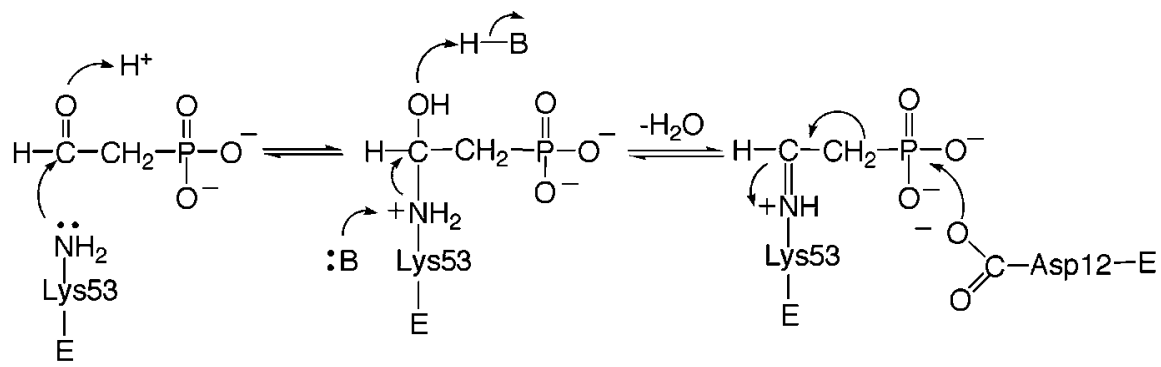

phosphonoacetaldehyde carbinolamine(I) substrate imine(II)

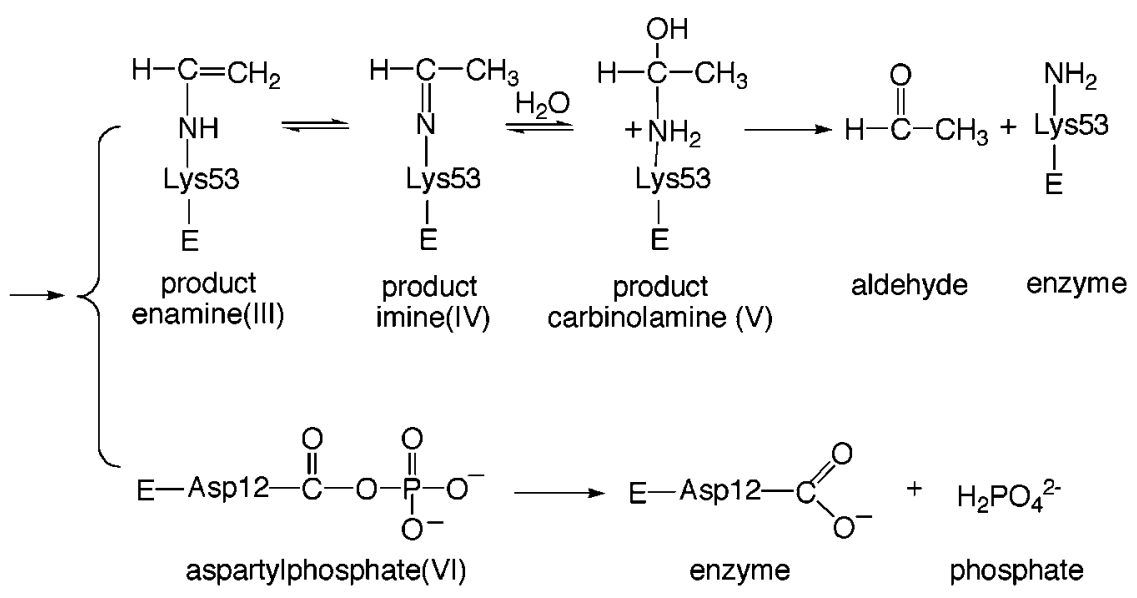

Fig. 3. Possible covalent intermediates formed during one catalytic cycle of the phosphonatase catalysis. 

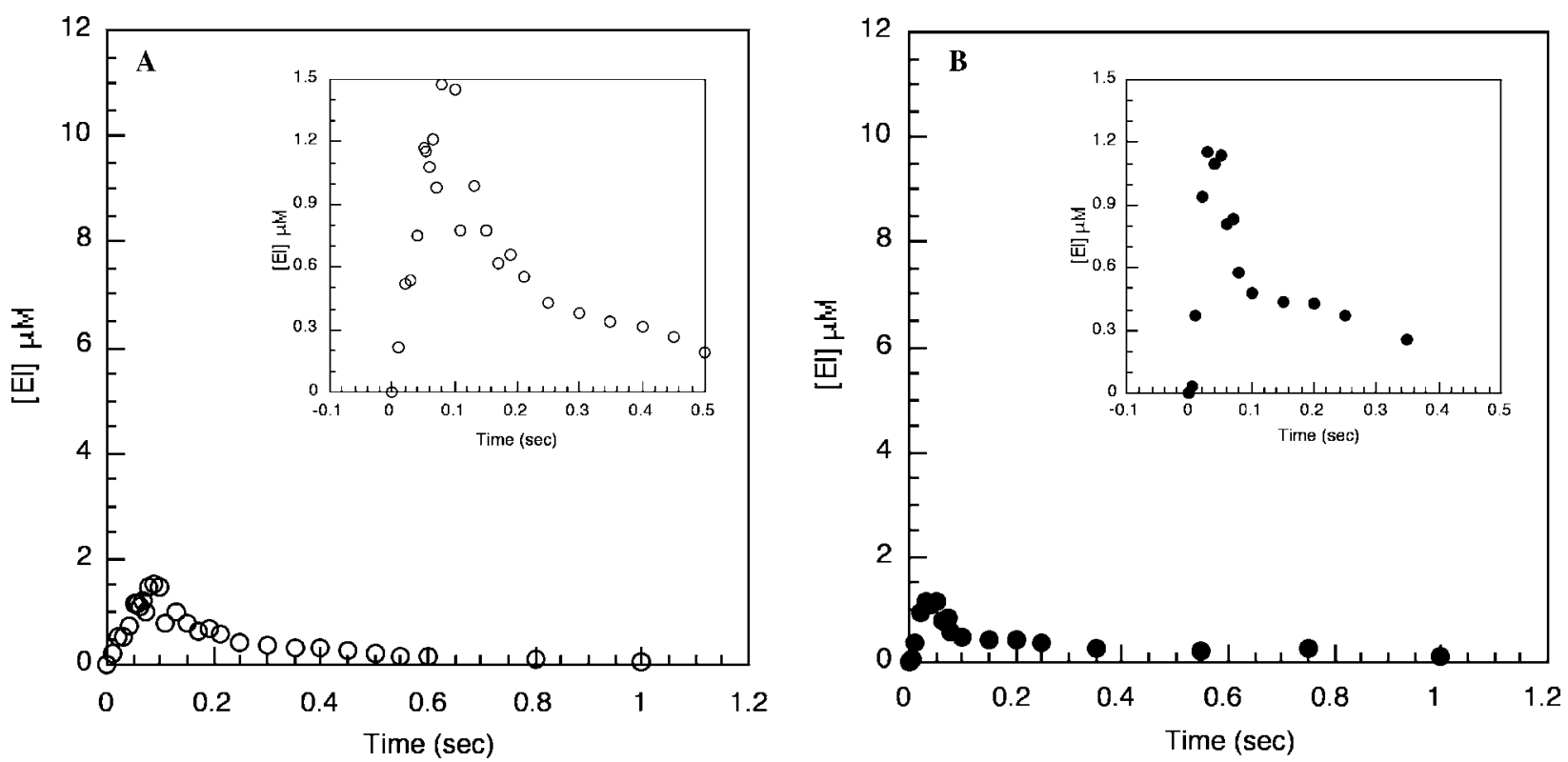

Fig. 4. Single turnover time course for the reaction of $500 \mu \mathrm{M}$ phosphonatase with $10 \mu \mathrm{M}$ radiolabeled Pald $\left((\mathrm{A})\left[1-{ }^{14} \mathrm{C}\right] \mathrm{Pald}\right.$ and $\left.(\mathrm{B})\left[{ }^{32} \mathrm{P}\right] \mathrm{Pald}\right)$ in $50 \mathrm{mM} \mathrm{K}+$ Hepes $\left(\mathrm{pH} 7.5,25^{\circ} \mathrm{C}\right.$ ) containing $10 \mathrm{mM} \mathrm{MgCl}_{2}$. The insets are the blowup views of the first $400 \mathrm{~ms}$.

in $\sim 325 \mathrm{~ms}$ (estimated by using the equation $t_{1 / 2}=$ $\ln 2 / k_{\text {cat }}$ and assuming a greater than $99 \%$ conversion at seven half-lives). Therefore, the time courses for the reactions of the $\left[1-{ }^{14} \mathrm{C}\right] \mathrm{Pald}$ and $\left[{ }^{32} \mathrm{P}\right] \mathrm{Pald}$ demonstrate the formation and consumption of the kinetically competent covalent intermediates. Future experiments, to be carried out with double-labeled Pald and with different chemical quenches, will determine the time courses for the individual intermediates.

This study demonstrates that the $\left[1-{ }^{14} \mathrm{C}\right]$ Pald and $\left[{ }^{32} \mathrm{P}\right] \mathrm{Pald}$ are useful probes in the study of the catalytic mechanism of phosphonatase. We anticipate their application in the investigation of Pald-dependent biochemical processes. Investigators may obtain the enzymes used in the synthesis of the radiolabeled Pald by writing to the corresponding author at the address provided.

\section{References}

[1] K.A. Johnson, Transient-state kinetic analysis of enzyme reaction pathways, The Enzymes XX (1992) 1-61.

[2] J.M. La Nauze, H. Rosenberg, The identification of 2-phosphonoacetaldehyde as an intermediate in the degradation of 2aminoethylphosphonate by Bacillus cereus, Biochim. Biophys. Acta 165 (1968) 438-447.
[3] A.S. Baker, M.J. Ciocci, W.W. Metcalf, J. Kim, P.C. Babbitt, B.L. Wanner, B.M. Martin, D. Dunaway-Mariano, Insights into the mechanism of catalysis by the P-C bond-cleaving enzyme phosphonoacetaldehyde hydrolase derived from gene sequence analysis and mutagenesis, Biochemistry 37 (1998) 9305-9315.

[4] S.V. Kononova, M.A. Nesmeyanova, Phosphonates and their degradation by microorganisms, Biochemistry (Mosc.) 67 (2002) 184-195.

[5] H.C. Wang, L. Ciskanik, D. Dunaway-Mariano, W. von der Saal, J.J. Villafranca, Investigations of the partial reactions catalyzed by pyruvate phosphate dikinase, Biochemistry 27 (1988) 625-633.

[6] G. Zhang, J. Dai, Z. Lu, D. Dunaway-Mariano, The phosphonopyruvate decarboxylase from Bacteroides fragilis, J. Biol. Chem., 2003, in press.

[7] Y. Jia, Z. Lu, K. Huang, O. Herzberg, D. Dunaway-Mariano, Insight into the mechanism of phosphoenolpyruvate mutase catalysis derived from site-directed mutagenesis studies of active site residues, Biochemistry 38 (1999) 14165-14173.

[8] G. Zhang, A.S. Mazurkie, D. Dunaway-Mariano, K.N. Allen, Kinetic evidence for a substrate-induced fit in phosphonoacetaldehyde hydrolase catalysis, Biochemistry 41 (2002) 13370-13377.

[9] J. Kim, D. Dunaway-Mariano, Phosphoenolpyruvate mutase catalysis of phosphoryl transfer in phosphoenolpyruvate: kinetics and mechanism of phosphorus-carbon bond formation, Biochemistry 35 (1996) 4628-4635.

[10] D.B. Olsen, T.W. Hepburn, M. Moos, P.A. Mariano, D. Dunaway-Mariano, Investigation of the Bacillus cereus phosphonoacetaldehyde hydrolase. Evidence for a Schiff base mechanism and sequence analysis of an active-site peptide containing the catalytic lysine residue, Biochemistry 27 (1988) 2229-2234. 